\title{
Ewa Gońda
}

Uniwersytet Ekonomiczny w Poznaniu

e-mail: e.gonda@ue.poznan.pl

\section{TAK ZWANY BUDŻET OBYWATELSKI \\ JAKO INSTRUMENT ALOKACJI ŚRODKÓW \\ PUBLICZNYCH W JEDNOSTKACH SAMORZĄDU TERYTORIALNEGO}

\section{THE SO-CALLED PARTICIPATORY BUDGET AS AN INSTRUMENT OF PUBLIC FUNDS' ALLOCATION IN THE LOCAL GOVERNMENT UNITS}

DOI: 10.15611/pn.2017.485.13

JEL Classification: H70, H72, H76

Streszczenie: Tak zwany budżet obywatelski, popularny w jednostkach samorządu terytorialnego w Polsce w ostatnich latach, pełni głównie funkcję alokacyjną. Celem artykułu jest próba udzielenia odpowiedzi na pytania: jaki powinien być zakres alokacji środków finansowych w ramach budżetu obywatelskiego oraz jak rozpatrywać efektywność i skuteczność takiej alokacji. Z rozważań wynika, że w ramach budżetu obywatelskiego powinny być realizowane tylko zadania własne. Mogą one mieć charakter obowiązkowy lub fakultatywny. Wskazane jest, aby miały one charakter projektowy, gdyż sprzyja to efektywności i skuteczności gospodarowania środkami publicznymi. Ponadto z artykułu wynika, że efektywność alokacji można rozpatrywać w kontekście poziomu potencjalnego zaspokojenia potrzeb, mierzonego liczbą głosów oddanych przez mieszkańców w stosunku do wydatków poniesionych na zadania. Natomiast skuteczność alokacji środków w ramach budżetu obywatelskiego wiąże się ze stopniem realizacji wyłonionych zadań.

Słowa kluczowe: budżet obywatelski, budżet jednostki samorządu terytorialnego, finanse lokalne, alokacja środków publicznych.

Summary: The so-called participatory budget has recently become popular within local government units, with allocation being its main function. The aim of this article is to answer the questions: what should be the participatory budget main areas of financial funds' allocation and how to measure efficiency and effectiveness of these allocations. This article shows that the participatory budget can be used for local government own tasks only. These tasks can be of obligatory or facultative nature. It is advisable to be of the project-type, as it contributes to the effectiveness and efficiency of public funds' management. In addition, the article shows that the effectiveness of allocation can be considered in the context of potential fulfilment of citizens' needs, measured by the number of votes related to the expenditures.

Keywords: participatory budget, local government budget, local finance, public funds' allocation. 


\section{Wstęp}

Od 2011 r., kiedy po raz pierwszy w Polsce, w Sopocie, zorganizowano tzw. budżet obywatelski ${ }^{1}$, stał się on dosyć popularny w jednostkach samorządu terytorialnego, w szczególności w dużych miastach ${ }^{2}$. Jest to spowodowane zaletami, którymi w powszechnym przeświadczeniu odznacza się budżet obywatelski. Często wskazuje się, że jest on narzędziem zwiększania zaangażowania mieszkańców w proces zarządzania jednostką samorządową, a tym samym służy budowie tzw. społeczeństwa obywatelskiego i demokratyzacji podejmowania decyzji w jednostkach [Kębłowski 2013, s. 14-15]. Oprócz tych zalet, istotnych głównie z socjologicznego i politologicznego punktu widzenia, wymieniane są zalety dotyczące pośrednio lub bezpośrednio finansów samorządowych. Podkreśla się bowiem, że budżetowanie partycypacyjne ułatwia identyfikację potrzeb mieszkańców, co umożliwia skuteczniejsze ich zaspokajanie oraz pozwala na bardziej efektywne gospodarowanie środkami finansowymi [Ministerstwo Cyfryzacji 2017; Poniatowicz 2014b, s. 181].

Istota budżetu obywatelskiego polega na dokonywaniu podziału określonej puli środków finansowych pomiędzy różne zastosowania, które zostały wskazane przez mieszkańców danej jednostki samorządu terytorialnego. Budżet obywatelski spełnia więc głównie funkcję alokacyjną. Mimo że skala tej alokacji nie jest dużaª ${ }^{3}$ ze względu na częste wykorzystywanie budżetu partycypacyjnego przez władze lokalne staje się on istotnym instrumentem finansowym w praktyce samorządowej. W związku z tym pojawiają się pytania m.in. o to, jaki powinien być zakres alokacji środków w ramach budżetu obywatelskiego oraz jak rozpatrywać efektywność i skuteczność takiej alokacji. Celem artykułu jest próba odpowiedzi na te pytania.

\footnotetext{
${ }^{1}$ Zamiennie stosowany jest również termin „budżet partycypacyjny”. Mimo powszechnego posługiwania się tymi pojęciami, należy stwierdzić, że ich stosowanie jest pewnym nadużyciem. W teorii finansów pojęcie „budżet” rozpatruje się bowiem w trzech aspektach: jako plan finansowy, akt prawny i fundusz [Denek, Sobiech, Wolniak 2001, s. 37; Owsiak 2006, s. 102]. Tzw. budżet obywatelski stanowi wydzieloną kwotę środków publicznych, o przeznaczeniu których mogą zadecydować mieszkańcy danej jednostki samorządowej. Nie jest to więc plan finansowy sensu stricto (obejmuje jedynie część wydatków budżetowych) ani akt prawny (postanowienia dotyczące tych wydatków są elementem uchwały budżetowej). Można go traktować jedynie jako „subfundusz”, będący wycinkiem większego funduszu - budżetu. Mimo tych zastrzeżeń, ze względu na powszechne posługiwanie się w literaturze pojęciami budżetu obywatelskiego i budżetu partycypacyjnego (por. np. [Poniatowicz 2014b; Marczak, Kępka 2016]), będą one stosowane również w tym opracowaniu.

${ }^{2}$ Przykładowo, w 2016 r. budżet partycypacyjny zorganizowano w 62 z 66 miast na prawach powiatu [Bednarska-Olejniczak, Olejniczak 2017, s. 60].

${ }^{3}$ Kwota środków finansowych rozdysponowywanych w ramach budżetu obywatelskiego zazwyczaj nie przekracza $1 \%$ wydatków budżetu danej jednostki samorządowej. Por. [Bednarska-Olejniczak, Olejniczak 2017, s. 61-62].
} 


\section{Zakres alokacji środków w ramach budżetu obywatelskiego}

Określenie zakresu alokacji środków budżetu obywatelskiego sprowadza się do wskazania rodzajów zadań, które powinny być finansowane w ramach tego budżetu. Bez wątpienia, ze względu na to, że środki te są środkami budżetu danej jednostki samorządowej, muszą one być wydatkowane na zadania, które mieszczą się w katalogu ustawowych zadań jednostki danego szczebla samorządu terytorialnego [Ruśkowski, Salachna (red.) 2010, s. 660]. Oznacza to, że zakres alokacji środków budżetu obywatelskiego jest ograniczony do zadań własnych jednostki samorządowej. Nie jest możliwe finansowanie w ten sposób zadań zleconych z zakresu administracji rządowej lub zadań innych jednostek samorządu terytorialnego, które są realizowane na podstawie porozumień. Są to bowiem zadania obce i - co do zasady - powinny być finansowane ze środków podmiotu zlecającego lub powierzającego dane zadanie.

Zadania własne dzielą się na zadania obligatoryjne i fakultatywne. Dyskusyjnym zagadnieniem dotyczącym zakresu alokacji środków budżetu obywatelskiego może więc być kwestia, czy w ramach tego budżetu powinny być finansowane zadania obligatoryjne, czy fakultatywne. Obowiązek wykonywania przez jednostki samorządu terytorialnego zadań obligatoryjnych został narzucony przez ustawodawcę ze względu na konieczność zagwarantowania zaspokojenia potrzeb wspólnoty samorządowej na przynajmniej minimalnym poziomie. Jednostka samorządu nie może uchylić się od wykonania tych zadań i musi zapewnić w swoim budżecie środki na pokrycie wydatków z nimi związanych [Kańduła, Przybylska 2008, s. 15]. Co więcej, jak podkreśla się w literaturze, wydatki na zadania obligatoryjne mają w znacznej mierze charakter wydatków sztywnych, których jednostka nie może dowolnie kształtować [Czarnecki 2014, s. 129]. W szczególności dotyczy to zadań związanych z polityką społeczną państwa, np. z zakresu oświaty, pomocy społecznej, które w znacznym stopniu podlegają działalności regulacyjnej państwa [Denek 2001, s. 11 i 23].

$\mathrm{Na}$ tle tych rozważań można wyciągnąć wniosek, że zadania obowiązkowe - przynajmniej na minimalnym poziomie - powinny być finansowane w ramach „właściwego" budżetu jednostki samorządowej, a nie budżetu obywatelskiego. Środki budżetu partycypacyjnego mogłyby być przeznaczane na zadania obligatoryjne w zakresie, który wykracza ponad pewne minimum zaspokojenia potrzeb. W tej sytuacji powstają jednak pytania: jak określić ten minimalny poziom oraz co zrobić w sytuacji, gdy mieszkańcy zgłoszą do realizacji zadanie dotyczące potrzeb podstawowych, które powinny być zaspokojone w ramach „normalnej” działalności jednostki samorządu terytorialnego ${ }^{4}$. Czy takie zadanie powinno być odrzucone i finansowane w ramach „właściwego" budżetu, czy też powinno być finansowane w ramach budżetu obywatelskiego, z uwzględnieniem, że tym samym zostaną za-

\footnotetext{
${ }^{4}$ Przykładem w tym zakresie jest zadanie zgłoszone do Poznańskiego Budżetu Obywatelskiego (dalej PBO) w 2016 r., polegające na umyciu kloszy lamp ulicznych w danym rejonie miasta.
} 
gospodarowane środki, które mogłyby być przeznaczone na zaspokojenie innych, ponadpodstawowych potrzeb?

Z kolei zadania fakultatywne - zgodnie z podejściem literaturowym - są podejmowane z inicjatywy jednostki samorządowej, w zależności od potrzeb występujących na jej terenie i możliwości finansowych [Sochacka-Krysiak (red.) 2008, s. 116; Wojciechowski 2012, s. 34]. Władze samorządowe powinny więc mieć samodzielność w zakresie zadań fakultatywnych, zarówno co do ich rodzaju, jak i sposobu wykonania. Tymczasem w praktyce samorządowej takiej samodzielności nie ma. W świetle rozstrzygnięć nadzorczych i orzecznictwa sądowego zadania fakultatywne mogą być bowiem wykonywane tylko wtedy, kiedy istnieje do tego wyraźna podstawa prawna [Jastrzębska 2011, s. 37, 39]. W odniesieniu do budżetu obywatelskiego należy więc zwrócić szczególną uwagę na to, czy zadania wyłonione przez mieszkańców mają taką podstawę. Nie zawsze potrzeby społeczne wpisują się bowiem w zadania danej jednostki samorządowej5.

$\mathrm{Z}$ organizacyjnego punktu widzenia zadania jednostek samorządu terytorialnego dzielą się na zadania projektowe i procesowe. Zadania projektowe mają charakter tymczasowy. W przypadku tych zadań istnieje możliwość precyzyjnego określenia ich początku i końca, a ich wykonaniem często zajmują się specjalnie wyodrębnione zespoły projektowe. $\mathrm{Z}$ kolei zadania procesowe są zadaniami ciągłymi. W odniesieniu do tych zadań trudno jest wyodrębnić datę początkową i końcową, choć często w trakcie ich realizacji występują istotne daty, związane np. z początkiem i końcem roku budżetowego. Najczęściej są one wykonywane w ramach tzw. struktury liniowej, czyli przez wyodrębnione komórki organizacyjne (np. wydział w urzędzie gminy) [Strojny 2014, s. 152].

Zadania projektowe, mimo tymczasowego charakteru, niejednokrotnie wywołują powstanie zadań ciągłych. Przykładowo, wybudowanie budynku w ramach zadania projektowego powoduje konieczność odpowiedniego jego zagospodarowania i ponoszenia wydatków związanych z jego utrzymaniem. Powstaje więc zadanie ciągłe, które będzie musiało być wykonywane w kolejnych latach. Jest to szczególnie istotne w kontekście budżetu obywatelskiego i zazwyczaj ograniczonych możliwości finansowych jednostek samorządu terytorialnego. Przeznaczając określoną kwotę na sfinansowanie wybranych projektów w ramach budżetu obywatelskiego, władze samorządowe nie mogą bowiem zapomnieć, że nie są to jedyne wydatki związane z tymi zadaniami i należy w odpowiedni, tzn. realistyczny sposób uwzględnić kwoty, które trzeba będzie przeznaczyć na utrzymanie efektów projektu w przyszłych latach.

\footnotetext{
${ }^{5}$ Wątpliwości może budzić np. wyłonienie do realizacji w ramach PBO 2016 zadania pn. „Winnice Poznania”. Założeniem pomysłodawców było obsadzenie winoroślami nadbrzeży rzeki Warty na odcinku $1 \mathrm{~km}$ i utworzenie w ten sposób ogrodu społecznego (,przez mieszkańców i dla mieszkańców”), z którego plonów mieszkańcy mogliby korzystać za darmo. Powstaje pytanie, czy takie przedsięwzięcie ma podstawę w ustawodawstwie dotyczącym zadań gminy lub powiatu.
} 


\section{Efektywność i skuteczność alokacji środków budżetu obywatelskiego}

Ograniczoność środków znajdujących się w gestii jednostek samorządu terytorialnego powoduje konieczność ich możliwie najbardziej racjonalnego wydatkowania. Od kilku lat w Polsce coraz większą wagę przywiązuje się do efektywności i skuteczności dokonywania wydatków publicznych, tym bardziej że pewne wymogi w tym zakresie zostały zawarte w przepisach prawnych. Zgodnie z ustawą o finansach publicznych wydatki publiczne powinny być bowiem dokonywane w sposób celowy i oszczędny, z zachowaniem zasad uzyskiwania najlepszych efektów z danych nakładów oraz optymalnego doboru metod i środków służących osiągnięciu założonych celów [Ustawa z 27 sierpnia 2009, art. 44 ust. 3].

Efektywność najczęściej jest rozpatrywana w ujęciu makroekonomicznym jako relacja między wartością poniesionych nakładów a wartością uzyskanych dzięki nim efektów [Poniatowicz 2014a, s. 6]. Odnosząc pojęcie efektywności do sfery finansów publicznych, przyjmuje się, że polega ona na ukształtowaniu wydatków publicznych w taki sposób, aby ich określony poziom umożliwiał osiągnięcie maksymalnej użyteczności społecznej. Dodatkowo w literaturze wskazuje się aspekty efektywności finansów samorządu terytorialnego. W ramach jednego z nich efektywność jest rozpatrywana w kontekście zaspokajania potrzeb publicznych danej społeczności lokalnej, z uwzględnieniem jej preferencji, dotyczących zakresu usług publicznych oraz sposobu ich finansowania [Guziejewska 2008, s. 71, 73].

Ze względu na znaczenie efektywności wydatków samorządowych można jej badanie odnieść do środków alokowanych w ramach budżetu obywatelskiego. Badanie efektywności tej alokacji jest niezwykle skomplikowane, ponieważ o ile łatwo można określić kwotę wydatków związanych z finansowanymi zadaniami, trudno jest zidentyfikować i skwantyfikować ich efekty. Wynika to m.in. z faktu, że efekty wydatków publicznych mają często charakter jakościowy [Poniatowicz 2014a, s. 7]. Dodatkowo zadania finansowane w ramach budżetu obywatelskiego są wykonywane w różnych okresach, nierzadko kilka lat po zakończeniu danej edycji budżetu obywatelskiego, efekty poszczególnych zadań pojawiają się więc nierównolegle i z opóźnieniem.

Mimo tych trudności można spojrzeć na efektywność alokacji środków budżetu obywatelskiego z innej perspektywy. Jak już wspomniano, jeden z aspektów efektywności dotyczy uwzględniania preferencji społeczności lokalnych w zakresie sposobu zaspokajania ich potrzeb. Wiąże się to więc z istotą budżetu obywatelskiego, która polega na wyrażaniu przez mieszkańców swoich preferencji odnośnie do wydatkowania określonej kwoty środków publicznych. W tym kontekście efektywność alokacji można zdefiniować jako relację między liczbą głosów oddanych na poszczególne zadania (będącą wyrazem preferencji mieszkańców) a wydatkami prze- 
znaczonymi na te zadania ${ }^{6}$. Im wyższa wartość wskaźnika, tym wyższa jest efektywność przysłowiowej „złotówki” wydatkowanej w ramach budżetu obywatelskiego. Oznacza to bowiem, że z wydatkowaniem tej złotówki wiąże się większa liczba mieszkańców głosujących na dane zadanie, których preferencje zostały uwzględnione.

Zagadnieniem, które często analizuje się w powiązaniu z efektywnością, jest skuteczność. Pojęcie to dotyczy poziomu osiągnięcia założonych celów oraz zgodności wyniku z celem [Poniatowicz 2014a, s. 7]. W przypadku budżetu obywatelskiego skuteczność alokacji środków może być rozpatrywana - w pewnym uproszczeniu jako stopień realizacji wyłonionych zadań. Najwyższy poziom skuteczności będzie osiągnięty, jeśli wszystkie zadania wybrane w ramach budżetu obywatelskiego zostaną wykonane w określonym czasie.

Tak rozumiana skuteczność zależy od kilku czynników. Można wśród nich wyodrębnić m.in. czynniki: prawne, organizacyjne i finansowe. W grupie czynników prawnych na pierwszy plan wysuwa się niejasny status budżetu obywatelskiego w przepisach prawnych. Najczęściej budżet ten jest traktowany jako forma konsultacji społecznych, które mogą być przeprowadzane z mieszkańcami jednostki samorządu terytorialnego (por. np. [Ustawa z 8 marca 1990, art. 5a ust. 1]). Wyniki konsultacji nie są wiążące dla organów samorządowych, a tym samym zadania wyłonione przez mieszkańców w ramach budżetu obywatelskiego nie muszą być uwzględnione przez władze samorządowe. Może to oddziaływać negatywnie na skuteczność alokacji środków.

Innym czynnikiem prawnym są regulacje dotyczące procedury budżetowej. Zgodnie z nimi jedynymi organami mającymi kompetencje $\mathrm{w}$ zakresie opracowania i przyjęcia budżetu danej jednostki samorządu terytorialnego są organ wykonawczy i organ stanowiący. Organ wykonawczy przygotowuje projekt uchwały budżetowej, natomiast organ stanowiący dokonuje jego autoryzacji [Ustawa z 27 sierpnia 2009, art. 233 i 239]. Decydowanie przez mieszkańców o kierunkach wydatków w ramach budżetu obywatelskiego nie ma więc wyraźnych podstaw prawnych [Czarnecki 2014, s. 130]. Można stwierdzić, że budżet obywatelski jest swoistą ,umową dżentelmeńską" między organem wykonawczym, organem stanowiącym i mieszkańcami [Radziszewski 2016, s. 51]. Usankcjonowana prawnie, decydująca rola organu stanowiącego powoduje jednak, że w przypadku np. konfliktów politycznych między organami wykonawczym i stanowiącym zadania wybrane przez mieszkańców i rekomendowane przez organ wykonawczy w projekcie budżetu mogą nie być uwzględnione w uchwalonym budżecie.

Czynniki prawne wpływające na skuteczność alokacji środków w ramach budżetu obywatelskiego są również związane z wyłonionymi zadaniami. Jak już wspomniano, aby jednostka samorządu terytorialnego mogła wykonać określone zadanie,

\footnotetext{
${ }^{6} \mathrm{~W}$ ten sam sposób można mierzyć efektywność w odniesieniu do całości budżetu obywatelskiego i porównywać uzyskane wyniki w czasie lub między różnymi jednostkami samorządu terytorialnego.
} 
musi istnieć do tego wyraźna podstawa prawna. W sytuacji jej braku zadanie wybrane przez mieszkańców nie może być zrealizowane, co powoduje nieskuteczność alokacji środków budżetu obywatelskiego.

Wśród czynników organizacyjnych wpływających na skuteczność omawianej alokacji istotne znaczenie ma sposób organizacji budżetu obywatelskiego, w tym zwłaszcza sposób organizacji procesu wyłaniania zadań poddawanych pod głosowanie mieszkańców oraz kwalifikacje zaangażowanych w tym zakresie pracowników samorządowych. Niejednokrotnie zadania zgłaszane przez mieszkańców są bowiem trudne lub wręcz niemożliwe do realizacji, ze względu na np. nieodpowiednie warunki środowiskowe lub brak prawa własności nieruchomości niezbędnej do wykonania zadania. Skuteczność alokacji środków zależy więc od dokonania rzetelnej selekcji zadań, w wyniku której pod głosowanie mieszkańców zostaną poddane tylko zadania możliwe do realizacji .

Czynniki finansowe wpływające na skuteczność alokacji środków w ramach budżetu obywatelskiego są związane z faktem, że na zadania wybierane przez mieszkańców przeznacza się zazwyczaj ściśle określoną kwotę. Bardzo ważna jest więc poprawność określenia wysokości środków finansowych niezbędnych do wykonania poszczególnych zadań. W praktyce często koszty zadań są niedoszacowane. Powoduje to, że wobec ograniczoności środków budżetowych dane zadanie nie jest wykonywane lub jest wykonywane w niepełnym zakresie. Także i w tym przypadku kluczowa rola należy więc do pracowników samorządowych, którzy powinni dbać o urealnianie planowanych wydatków związanych z zadaniami wybieranymi w ramach budżetu obywatelskiego.

\section{Zakończenie}

Z przedstawionych rozważań wynika, że zakres alokacji środków w ramach budżetu obywatelskiego jest ograniczony do zadań własnych jednostki samorządu terytorialnego. W ocenie autorki zadania finansowane ze środków tego budżetu mogą dotyczyć - z pewnymi zastrzeżeniami - zarówno zadań obligatoryjnych, jak i fakultatywnych. W przypadku zadań obligatoryjnych nie powinny to być jednak zadania podstawowe, które jednostka samorządu terytorialnego jest zobowiązana finansować w ramach „właściwego" budżetu, dotyczące np. utrzymania czystości na ulicach lub remontu budynku szkoły. Z kolei w odniesieniu do zadań fakultatywnych, ze względu na dominujące stanowisko organów nadzoru i sądów administracyjnych, należy zwracać szczególną uwagę, czy zadania zgłaszane przez mieszkańców mają

\footnotetext{
${ }^{7}$ Przykładami nieskutecznej alokacji środków mogą być dwa zadania wyłonione w ramach PBO 2016: wspomniane wcześniej „Winnice Poznania” i „Taras widokowy na ratuszu miejskim”. Pierwsze zadanie okazało się niemożliwe do realizacji ze względów klimatycznych i glebowych. Drugie zadanie nie mogło być wykonane ze względu na brak zgody właściciela nieruchomości i możliwości technicznych budowy tarasu. W obu przypadkach okoliczności uniemożliwiające realizację zadań mogły być zidentyfikowane przed umieszczeniem zadań na liście do głosowania.
} 
podstawę prawną, która umożliwia ich wykonanie przez daną jednostkę samorządową.

Biorąc pod uwagę organizacyjny aspekt zadań, zdaniem autorki zadania wyłonione w ramach budżetu obywatelskiego powinny mieć charakter projektowy. Specyfika projektu, polegająca na skoncentrowaniu wyodrębnionych zasobów na danym zadaniu, precyzyjnie określonym w czasie, pozwala bowiem na mierzenie efektów zadania. Jest to szczególnie istotne w kontekście efektywności i skuteczności gospodarowania środkami publicznymi. Jednocześnie należy pamiętać o tym, że zadanie projektowe może wywołać powstanie zadania ciągłego związanego z utrzymaniem efektów projektu w kolejnych latach.

Odnośnie do efektywności i skuteczności alokacji środków finansowych należy stwierdzić, że w przypadku budżetu obywatelskiego są to zagadnienia złożone. Badanie efektywności jest utrudnione ze względu na zróżnicowane, nierzadko nieporównywalne i odsunięte w czasie efekty zadań realizowanych w ramach budżetu obywatelskiego. W tej sytuacji efektywność można rozpatrywać w odniesieniu do poziomu potencjalnego zaspokojenia potrzeb, mierzonego liczbą oddanych głosów w stosunku do poniesionych wydatków. Natomiast skuteczność alokacji może być analizowana w kontekście stopnia realizacji zadań, które zostały wyłonione przez mieszkańców. W ocenie autorki skuteczność ta może być zwiększana poprzez lepsze przygotowanie i lepszą selekcję zadań poddawanych pod głosowanie mieszkańców.

\section{Literatura}

Bednarska-Olejniczak D., Olejniczak J., 2017, Participatory budgeting in Poland - finance and marketing selected issues, The International Conference Hradec Economic Days 2017. Economic Development and Management of Regions. Peer-Reviewed Conference Proceedings, red. P. Jedlicka, P. Jedlicka, Gaudeamus, s. 55-67.

Czarnecki K., 2014, Udział mieszkańców w ustalaniu wydatków budżetu gminy w ramach tzw. budżetu partycypacyjnego (na przykładzie Torunia w latach 2013-2014), Prawo Budżetowe Państwa i Samorządu, nr 2, s. 125-145.

Denek E., 2001, Płaszczyzny rozpatrywania samodzielności samorządu terytorialnego, Zeszyty Naukowe Akademii Ekonomicznej w Poznaniu, nr 7, Samodzielność samorządu terytorialnego w Polsce, red. E. Denek, Wydawnictwo AE, Poznań, s. 7-27.

Denek E., Sobiech J., Wolniak J., 2001, Finanse publiczne, Wydawnictwo Naukowe PWN, Warszawa.

Guziejewska B., 2008, Efektywność finansów samorzadu terytorialnego, Gospodarka Narodowa, nr 5-6, s. 71-89.

Jastrzębska M., 2011, Fakultatywne zadania własne gminy w świetle obowiazujacych regulacji prawnych, Finanse Komunalne, nr 1-2, s. 35-42.

Kańduła S., Przybylska J., 2008, Organizacja działalności gospodarczej samorządu terytorialnego w Polsce, Wydawnictwo Akademii Ekonomicznej w Poznaniu, Poznań.

Kębłowski W., 2013, Budżet partycypacyjny. Krótka instrukcja obsługi, Instytut Obywatelski, Warszawa, http://www.instytutobywatelski.pl/wp-content/uploads/2013/03/budzet_partycypacyjny.pdf (23.03.2017). 
Marczak J., Kępka K., 2016, Budżet partycypacyjny w Polsce na przykładzie budżetu obywatelskiego miasta Łodzi. Analiza finansowa, Samorząd Terytorialny, nr 1-2, s. 42-64.

Ministerstwo Cyfryzacji, 2017, Budżet partycypacyjny, https://mac.gov.pl/budzet-partycypacyjny (23.03.2017).

Owsiak S., 2006, Finanse publiczne. Teoria i praktyka, Wydawnictwo Naukowe PWN, Warszawa.

Poniatowicz M., 2014a, Instrumenty nowoczesnego zarządzania finansami w kontekście efektywności, sprawności i skuteczności działania jednostek samorządu terytorialnego, Finanse Komunalne, nr 7-8, s. 5-12.

Poniatowicz M., 2014b, Kontrowersje wokót idei budżetu partycypacyjnego jako instrumentu finansów lokalnych, Studia Ekonomiczne - Zeszyty Naukowe Wydziałowe, nr 198, Finanse - Problemy - Decyzje. Część 1, red. T. Famulska, K. Znaniecka, Uniwersytet Ekonomiczny w Katowicach, s. $177-188$.

Radziszewski M., 2016, Wybrane instrumenty wykorzystywane w procesie budowy spoleczeństwa obywatelskiego, Samorząd Terytorialny, nr 6, s. 49-60.

Ruśkowski E., Salachna J. (red.), 2010, Nowa ustawa o finansach publicznych wraz z ustawa wprowadzająca. Komentarz praktyczny, ODDK, Gdańsk.

Sochacka-Krysiak H. (red.), 2008, Gospodarka finansowa jednostek samorzadu terytorialnego w warunkach decentralizacji zarządzania sektorem publicznym, Szkoła Główna Handlowa w Warszawie, Warszawa.

Strojny J., 2014, Organizacyjne i proceduralne uwarunkowania zarzadzania projektami $w$ jednostce samorzadu terytorialnego, Modern Management Review, nr 2, s. 149-160.

Ustawa z 8 marca 1990 r. o samorządzie gminnym, t.j. Dz.U. 2016, poz. 446 ze zm.

Ustawa z 27 sierpnia 2009 r. o finansach publicznych, t.j. Dz.U. 2013, poz. 885 ze zm.

Wojciechowski E., 2012, Gospodarka samorządu terytorialnego, Difin, Warszawa. 